\title{
Life and Afterlife of Sädrrśya: Revisiting the Citrasūtra through the Nationalism-Naturalism Debate in Indian Art History
}

\author{
Parul Dave-Mukherji
}

This paper sets out to revisit the Citrasūtra, a seminal section on painting from the Viṣnudharmottarapurāna, in the light of key concerns around the cultural politics of art historiography, the śāstra-prayoga debate (Maxwell 1989, 5-15), and the related question of interpretative frameworks for studying early Indian art. The latter concern has lately come to the forefront in the context of postcolonial studies and global art history. It is critical of intellectual parasitism (Dhareshwar 2015, 57-77) and pushes postcolonial thought to explore 'native' interpretative frames to study Indian art (Asher 2007, 12).

This paper attempts to complicate the search for alternative frameworks by underlining gaps and slippages that surround the meaning of terms in a given text and their modern appropriations. To this end, it traces the genealogy of the term sādrśya, from the śilpaśāstric lexicon through its twentieth-century reception in art-historical discourse. How does a term acquire an afterlife when it enters into the force field of reinterpretation steeped in cultural nationalism? How could a newly "discovered" Sanskrit text function in such a space? ${ }^{1}$

In this paper, I also intend to address the larger question: what is the genealogy of the view of India's cultural past, and specifically its "art," as transcendental/ idealistic/spiritual, which has translated itself into a belief? And why does this belief persist, although in different configurations? In more recent times, an ethnographic approach to the study of texts has emerged as a corrective, which I will critically examine for its relevance for alternative interpretative frames for the study of Indian art. In the end, I will conclude by relating Coomaraswamy's transcendentalism to David Shulman's recent dis-

1 The first printed text of the Viṣnudharmottara Purāna, edited by Pandit Madhusudhan and Madhavaprasada Sarma in 1912 (Venkateshwar Press, Bombay), is the one that caught the attention of a pioneering art historian, Stella Kramrisch, who had arrived in India from Vienna. It was her English translation which brought the text into the discourse of art history and Indology. 
course around the 'more than real' (Shulman 2012), and the latter's implication for interpretative frameworks for Indian art.

It is around the first quarter of the twentieth century that some major textual sources, either complete or as fragments, were "discovered," edited and translated. They began to acquire tremendous cultural significance as carriers of authentic meaning. One such text was the Citrasūtra of the Viṣnudharmottara, which emerged on the stage of art history in India when it was first translated into English in 1924 by Stella Kramrisch, the pioneering historian of Indian art. This art historian from Vienna chanced upon this text soon after her arrival in India in 1919. The first printed text of the Viṣnudharmottara Purāna, edited by Pandit Madhusudhan and Madhavaprasada Sarma and published by the Venkateshwar Press, Bombay in 1912, is the one that caught attention of Kramrisch. It was her English translation (Kramrisch 1928 [1924]) which brought the text into the discourse of art history and Indology.

It was almost a decade later that another pioneering art historian, A.K. Coomaraswamy, turned his attention to this text, singling out one of its chapters, adhyāya 41, for translation and commentary (Coomaraswamy 1933, 13-21). This chapter of the text deals with the classification of painting into four typesSatya, Vainika, Nāgara and Miśra. According to Coomaraswamy, the first two types corresponded to the pictorial tradition of the Ajanta caves.

By now, the two most eminent art historians of Indian art who played a seminal role in establishing the discipline of art history in India were involved in the interpretation of the Citrasütra. This, in turn, exalted the status of the text and transformed it into an Ur-text for a wide-ranging extrapolation about Indian art and aesthetics, which continued into the first decade of the 21st century (Nardi 2006).

Almost twenty-five years separate Coomaraswamy's commentary on the text and its first critical edition, brought out by a Sanskritist, Priyabala Shah in 1958 and 1961. Shah's edition broke fresh grounds in textual criticism when she incorporated the readings from six new manuscripts. However, her attempt at theorization was restricted, interestingly, to the same chapter selected by Coomaraswamy, which dealt with the classification of paintings. She was far too involved with connecting the types of paintings with types of architectural styles to pay attention to whether Coomaraswamy's metaphysical readings of the terminology were borne out by the edited text. Exactly two decades later, interest in this text was renewed when another art historian, C. Sivaramamurti 
published a translation and commentary of all nine chapters of the Citrasūtra (1978). A Sanskritist and an art historian of post-independent India, Sivaramamurti assigned a diametrically opposite significance to the text, one validating "Indian naturalism" as opposed to the manner in which Coomaraswamy used this text as a support for his claims of transcendentalism during the colonial period.

The interpretation of the Citrasūtra is further complicated by the fact that it was "discovered" in colonial India; this implied that its interpretation would be caught in a comparative framework involving the art of the colonizer and that of the colonized. The central question around which the art of India and that of the West were compared and judged was that of 'naturalism,' a term that was seen as intrinsic to the identity of western art.

When the Citrasütra came to light in the early decades of the twentieth century, cultural nationalism was at its height and art history as a discipline was being introduced into Indian universities. Naturalism supplied a key term, often as an antithesis to ornamentalism, around which debates on the worth of Indian art and craft were being carried out amidst the ascendency of cultural nationalism. Transcendentalism and naturalism are dialectically connected as part of a discourse largely constructed by A.K. Coomaraswamy to place Indian art on a morally higher plane. The former stands for Indian art and its spiritual interiority, defined in contrast to the naturalism ascribed to Western art. There prevailed a climate of contestation rife with orientalist binaries that pitted the 'rational,' 'scientific' West with the 'mystical,' 'irrational' India (Masson-Oursel 1925). ${ }^{2}$ If Indian art is believed to be the result of the artists' power of meditation, Western art is assumed to capture only the surface of nature or the visible world but never its inner essence. Hence the imbrication of the naturalism debate within nationalism. In the battle between the superiority of naturalism in art as a hallmark of Western control over representation and its rejection by

2 Paul Masson-Oursel, a French Orientalist, exerted a strong influence on Coomaraswamy. It is to be noted that Coomaraswamy found strong support for his views in Masson-Oursel's writings and in fact translated Masson's 1925 article "Une connexion entre l' esthétique et la philosophie de l' Inde: la notion de pramâna" (Review des Arts Asiatique 2, 1: 6-9) into English as "A Connection between Indian Aesthetics and Philosophy in India" (Rupam 27 \& 28 [1926]: 91-94). 
Indian nationalists for the higher civilizational ideal of transcendentalism, the latter won the day. Its victory placed Coomaraswamy at an advantageous position, and today this discourse has come to assume truth value, constituting a common sensibility concerning Indian art (Dehejia 1996).

For transcendentalism to emerge as an effective discourse to counter colonial presuppositions about Indian art, such as the denial of the existence of fine arts in India, an alliance of Art History with Indology was the need of the day. Already by the middle of eighteenth century, the discipline of Indology had been founded, having as its main objective the study of Indian culture through texts. Indology, right from its inaugural moment, operated with the assumption that it was ancient and classical Indian texts that were the most authentic means of recovering India's past (Halbfass 1981).

Around the early 1920s, art history came to be introduced in an Indian university when the Vienna-trained art historian, Stella Kramrisch, began to teach this discipline in Kalabhavana, Visvabharati University, Santiniketan, at Rabindranath Tagore's behest. In other universities where it was taught, such as Calcutta University and Banaras Hindu University, it was as an adjunct to ancient Indian history. It was in 195os that an independent department of Art History and Aesthetics came to be established in the Faculty of Fine Arts, Msu, Baroda. This discipline was mobilized for the reconstruction of India's past, part of the nationalist project to regain the lost essence of Indian-ness as a means of reclaiming subjectivity (Guha-Thakurta 1991).

\section{Coomaraswamy's Reading of the Citrasūtra: A Founding Moment in Indian Art History}

So strong was Coomaraswamy's commitment to transcendentalism that it impelled him to interpret the traditional śilpaśāstras through the same lens. I have discussed his negotiation with the anomaly posed by the śilpaśāstras elsewhere (Dave-Mukherji 2008, 132-134). Let us see how the term sādrśya gets inflected by his translation. As a case in point, let us turn to Coomaraswamy's translation of adhyāya 41 of the Citrasūtra, which primarily defines four categories of painting: Satya, Deśika, Nāgara and Miśra. He particularly focused on the first category, as it seemed to pose a challenge to his assumption that there is no place for naturalism in Indian art. In fact, the very term Satya may be translated as "real" or "naturalistic" in light of its definition—-that any painting bearing resemblance to the world belongs to this category:

yat kiñcil lokasādrśyam citrạ̣ tat satyam ucyate 
I have translated this as follows (Dave-Mukherji 2001, 159):

Whichever painting that bears a similarity with the world [that painting] is called Satya ("Naturalistic").

This is in fact in wide variance with Coomaraswamy's translation $(1933,13)$ :

Painting that represents any of the worlds (kiñcilloka-sādrśya) ... is called Pure or Sacred (satya).

How satya comes to translated as "Pure or Sacred" is not a matter of willful mistranslation. Rather, we need to historicize this mode of interpretation and ask, under what conditions may satya be taken as "Pure or Sacred"? Satya could no longer be accepted as "True to life", as interpreted by Kramrisch $(1928,51)$. Another term, which intensified this problem, was sādrśya, which could not be allowed to retain its usual sense (Coomaraswamy 1933, 21):

If we understood sādrśya then to mean "illusion" or "realism," verisimilitude of any crude or naive sort, we should be contradicting all that we know of the oriental conception of art.

It was the co-existence of satya with sādrśya (resemblance/likeness) which compounded Coomarsawamy's problem of avoiding literal translation. Hence Coomaraswamy was compelled to connect yatkiñcilloka- with sādrśyam, against the rules of Sanskrit syntax, in order to yield the meaning "any of the worlds" in place of "any painting." His translation (Coomaraswamy 1933, 13) continues as follows:

Painting that represents any of the worlds (yatkiñcillokasādrśya), that is elongated and has ideal proportions ... [emphasis added]

In fact, the description of the painting as "elongated" (dìrghāngam) and having "ideal proportion" (supramānam) belongs to the next category of painting, termed Deśika. By misreading in this manner, he could explain away the naturalistic potential in the term sādrśy $a$ and impose his view of idealism being the essential feature of Indian painting (Coomaraswamy 1933, 13):

So also in verse 2 above, where kiñcilloka must include devaloka ["abode of the gods"], sādrśya cannot be interpreted as "naturalistic." 
Coomaraswamy's departure from normal Sanskrit syntax and semantics did not go unnoticed, but invited ridicule from his contemporary, a well-respected Sanskrit scholar (Raghavan 1933, 905): ${ }^{3}$

Satya cannot be interpreted as a Sattvika picture. One can as well derive it from Sat and say it is the picture of the Upanisadic Brahman.

In response to Raghvan's criticism, Coomaraswamy revised his translation of satya from "Pure or Sacred" to "intellectual and ideal" (Coomaraswamy 1933, 26), and rejected its literal meaning, which was however subsequently reinstated by Priyabala Shah $(1961,120)$ in the first critical edition of this text:

Whatever (yatkiñcid) painting depicts semblance of the world (Lokasādrśyam citram) is called Satya.

Coomaraswamy evidently felt in need of more support for his elimination of the concept of resemblance than the Citrasütra could provide. He began to look to the idealist schools of Upanisadic philosophy and epistemology (Coomaraswamy 1933, 26) to arrive at a metaphysical reworking of the term satya:

Satya is "real", "actual", "intelligible", "ideal"; nāmarūpa, "form" as distinct from the natural disorder (anrta) of the sensible world (loka) (Brhad $\bar{a}$ raṇyaka Upanișad, 1, 6, 3: Taittiriya Upanișad, II, 6).

In his recasting of sādrśya, Coomaraswamy turned to a rather unexpected source for an alternative definition of imitation in art that could preserve the term, but be free of the unwanted association of naturalism. He found what he was looking for in western medieval sources. In my view, this detour to the western medieval sources was not fortuitous but compelled by Coomaraswamy's confrontation with the Citrasūtra. This is confirmed by evidence of the period for his new interest, as given by his biographer, Roger Lipsey. According to Lipsey $(1977,73)$, the beginning of the 1930's marks the period of transformation for Coomaraswamy: “... it is just at this point that the relation to medieval Christian thought changed from an enthusiastic but transient acknowledgement of

3 Raghavan further comments, "My impression on reading the Viṣnudharmottara is that even to its author the exact import of these names was not clear. The text seems to have been written after a cut in the flow of tradition of the artists who were using these words as paribhāṣās." 
the value of Meister Eckhart in particular to a permanent and scholarly interest in the entire scholastic tradition from its origins in the St Augustine to its flowering in the thirteenth century."

For Coomaraswamy, medieval Christian thought best illuminated how to interpret sādrśya without any 'naturalistic' connotations (1933, 26):

Now as to Visnudharmottara, III, 41, 1 and 9, kimcit is not "any" but "somewhat"; loka not here "worlds" but the sensible (not alaukika) aspect of the world; sādrśya is not "resemblance" but consonantia, adaequatio rei et intellectus, ...

Combining references to western medieval sources with the terms from Indian epistemology, Coomaraswamy $(1933,26)$ arrives at a new definition of the satya type of painting as

... sāhitya, sādhärānnya, all of which have reference to unity self-contained in art, and not to likeness (sādrśatā) to a model. Kimcilloka-sādrśya is then "the unity of which is only somewhat as to the world, ...".

For Coomaraswamy, sādrśya with its naturalistic implication and its coexistence with satya, translated as "Pure," was contradictory. Here, purity is taken as a "unity self-contained in art," and for that reason the potential of referentiality to the world outside implied by the term sādrśya was viewed as posing a threat to his construct of art as the realm of the mind. In another instance, he qualified this term as "a consent (sädrśya) of pictorial and formal elements in the substance (śarira) and essence (ätman) of the work" (Coomaraswamy 1933, 27). While he conceded to some presence of pictorial realism in the other three types of painting, it is the first type or Satya through which the ethical notion of art as "Truth" could be admitted as that which had to be elevated beyond any reference to this realism (ibid.):

... and this contrasts with vainika and nägara painting in which it is to be understood that the realistic, pictorial (sādrśa) element is much greater, where accordingly an adaequatio (tadākāratā) rei et intellectus, sādrśya, is only partially attainable.

Notice a distinction created between sadrśa (which allows an element of pictorial realism) and sādrśya (a consent of pictorial and formal elements) was crucial for his interpretation to avoid contradicting "all that we know of the oriental conceptions of art." Rather than unpacking "the oriental conceptions 
of art," Coomaraswamy ended up congealing the old binaries between a rational occident and a spiritual orient. His 'cultural unconscious' is betrayed in a footnote in which he claims to have captured the voice of tradition through his alleged fidelity to the textual sources (Coomaraswamy 1933, 27).

What follows is derived from all these sources without the addition of any thought or phrase of my own. Verbal authority could be cited for any statement.

What relevance this kind of interrogation has for us today, this reaching back to the cultural politics of the early-twentieth century, also needs to be addressed. The transcendentalist claim made by Coomaraswamy on the basis of a "found" textual tradition can be explained as a political exigency for combating the colonial representation of Indian art. However, when such reliance on 'scriptural evidence' is perpetuated in postcolonial times, its inbuilt essentialism can have serious implications today in an India that is witnessing an unprecedented obsession around nationalism.

Foregrounding the claim that rejection of naturalism by Indian artists was intentional, Coomaraswamy effectively undercut the criticism that Indian art was deficient in naturalism. He suggested, instead, that it was never the intention of the Indian artists to imitate the visible world but to create a symbolic image based on a supramundane ideal which transcended the world of appearance. The charge leveled against Indian art of crude execution and a lack of anatomical accuracy (Ruskin 1905, 347) in the rendering of human and animal form was answered not by questioning the criteria of execution and cultural knowledge of bodies, but by claiming that these so-called "deficiencies" were deliberate, a result of a "specialized technique of vision" (Coomaraswamy 1934, 166):

Technical production is thus bound up with the psychological method known as yoga. In other words, the artist does not resort to models but uses a mental construction and this condition sufficiently explains the cerebral character of the art, ...

The vision of the classical Indian artist that emerges from Coomaraswamy's early writings appears to be modelled upon the idea of sculpture of dhyanni Buddhas, with artistic activity relegated to the domain of pure mental contemplation (Coomaraswamy 1908). The eyes of the artist appear to be visualized as half-closed, focused more on the inward, contemplative space of the mind and less on the world "out there," the domain of naturalism. With an ingenious 
reversal of binaries set up by the colonial critics, Coomaraswamy constructed a compelling counter-narrative, but in the process, he reproduced the very colonialist logic he had set out to resist.

Certainly, Coomaraswamy's transcendentalist claims for Indian art and aesthetics did not remain uncontested, as demonstrated by V. Raghavan's (1933) criticism of Coomaraswamy's interpretation and by the translators of the Citrasütra. However, such voices of dissent were relegated to the margins and rarely made an impact on the disciplinary framework of Indian art history, where Coomaraswamy's theoretical framework has retained a canonical status. Most curiously, Kapila Vatsyayan, in her very Foreword to my edition of the Citrasütra has cited the same verse that I have used to critique Coomarawamy's transcendentalist standpoint in order to justify it. The tenacity of this view can be gauged by the manner in which Coomaraswamy's misreading of pratyakșa, direct perception, as the least important pramāna or source of knowledge in Indian epistemology, is ratified by Vatsyayan (Dave-Mukherji 2001, xiii-xiv). In fact, all the six classical darśanas of Indian philosophy consider pratyakșa the most salient source of knowledge (Matilal 1986).

\section{4 \\ The Citrasūtra in Postcolonial Art Historiography: \\ C. Sivaramamurti}

The return of interest in the Citrasūtra in the work of C. Sivaramamurti in the late 197os signals a re-appropriation of this text within his agenda of cultural nationalism. Ostensibly, his turn to this text was to eradicate false readings and restore it closer to its original state (Sivaramamurti 1978, xv). Underscoring his interpretation of the Citrasūtra was the claim that naturalism was accorded a positive role both in Indian art and in the text, which resonated with the stand taken by him more than four decades earlier (Sivaramamurti 1934, 189):

Questions of perspective and foreshortening do not appear to have baffled the old artists of our land as in evident from their talks on such technical details as ksayavrddhi and the actual conformance of the pictures to those rules so elaborately discussed in books on theory.

It is largely the presence of terms such as sādŕsya and ksayavrddhi (literally "decrease and increase," i.e. "foreshortening," a technique used to show apparent depth in naturalistic art) that indicated to Sivaramamurti that the traditional Indian artist was no less proficient in representing the world "naturalis- 
tically" than his western counterpart. In a similar move, he looks beyond the context of the śilpaśästras, examining classical Sanskrit literature, and finds further evidence of imitation in art, as for example, in the Mṛcchakațikā (Sivaramamurti 1934, 189):

The tendency of imitation in an artist given in the Mrchhakațikā is healthy sign of progress at a particular stage provided it is directed in the right direction.

Thus by placing the śilpaśāstras in this wider context, Sivaramamurti retrieved key terms such as sādrśya, anukrti and kșayavrddhi from the framework of transcendentalism. Sivaramamurti reinstated naturalism in post-colonial India as an index of 'progress', as proof that India could measure up, and more, to the categories and standards of art set up in and by the West. Indeed, he writes naturalism back into the art-historiographical demands of post-colonial India, mapping the term powerfully onto nation building.

For me, the rejection of naturalism in Indian art on grounds of its western identity is as problematic as its nativist retrieval in Sivaramamurti's interpretation of the Citrasūtra. Interestingly, Sivaramamurti's espousal of an Indian naturalism met with deep skepticism from Stella Kramrisch, who was invited to write the foreword by the author (Sivaramamurti 1934, 10):

If as the text shows and Dr. Sivaramamurti stresses, realism was a main consideration with the painters, their criteria of verisimilitude were, no doubt, met in practice, although no object painted in the murals of Ajanta, which are roughly contemporary with the Chitrasūtra would strike a spectator today as being realistically painted. The realism is in the eye of the beholder and pious stories told, though not in the Chitrasūtra ...

Kramrisch almost poses as a paradox the gap between the ancient painters' intentions to accomplish realism and their actual practice, and argues that the premodern criteria of representation do not match up with our modern expectations of verisimilitude. Today, it is possible to see an overlap between Kramrisch's skepticism about Sivaramamurti's literal reading of the mimetic terms in the Citrasūtra and David Shulman's (2012) recent problematization of 'the real' in the context of his study of the South Indian models of mind.

In his reading of a seventh-century playwright, Harșadeva's classical Sanskrit drama, Ratnāvali, Shulman foregrounds the role of painting in the way the plot unfolds. About the question of verisimilitude, which emerges when the characters recognize each other in their respective portraits, Shulman arrives at a 
paradox similar to Kramrisch's, but resolves it by stressing the realm of imagination (Shulman 2012, 28):

Apparently, the painted image is recognized not so much by virtue of how it is painted but mostly as a prop for projection, ...

At one stroke, if Kramrisch evacuates realism/naturalism (taken interchangeably in this context) from both the walls of Ajanta and the text of the Citrasütra, Shulman edges it from the painted surface to the space of literary imagination. Naturalism or 'the real' is discursively edged off to the realm of the mind via the "eyes of the beholder" and the physical entity of a painting reduced to a "prop for projection." Despite her reservations about claims of verisimilitude in the Citrasūtra, Kramrisch had earlier accepted cultural specificity in visual representation. This view implicitly allowed for "Indian naturalism," even if her example draws from Chinese and European naturalism (Kramrisch 1922, 25):

The Chinese naturalism to the European eye appears as an idealistic abstraction, while the European naturalism strikes the Chinese as ugliness.

However, it is instructive to recognize the difference between Kramrisch and Shulman's skepticism about the claims of the real. Kramrisch, to some extent, was able to accommodate naturalism as a culturally specific phenomenon that manifested in art theory, if not in practice, while Shulman relegates the question of painterly resemblance solely to the domain of imagination. However, such a categorical dismissal of verisimilitude assumes a wide gap not only between discourse and practice but also between how the Indian mind thinks, how the Indian eyes see and how Indian bodies act; thinking, vision and agency are assumed to fall outside of any rational intentionality.

What needs examination is the persistence of a belief that ancient Indian art willfully rejected any empirical interest in the world that surrounded the artists. In my view, the theoretical framework of what this belief (i.e. in transcendentalism) was once a part of has faded into the background, turning the belief and the problematic produced by that theory into a widely-shared yet questionable sensibility concerning India's past and art traditions. Rather than a simplistic retrieval of an "Indian naturalism," as attempted by Sivaramamurti, the very semantic framework of the real operating in the silpaśāstras and literary texts needs to be unpacked and thought through. 
Since the inception of art history in India in the late eighteenth century, the core of the discipline came to be defined by a "detailed study of archeological evidence using a stylistic approach" (Maxwell 1989, 5). Despite the momentous "discovery" of the silpaśästras inaugurated by the coming to light of the Mānasāra in 1834, and by subsequent work on the Citralakșaṇa, Citrasūtra, Mānasollāsa and other sources around the early-twentieth century, these have still not been adequately explored for developing interpretative frameworks of art history in India. As pointed out by Tapati Guha Thakurta $(1991,170)$ in the context of Bengal, a sharp divide arose between history and aesthetics, as between archeology and the study of śilpa texts, when modern commentaries on ancient texts came to be written by the late-nineteenth and early-twentieth centuries: ${ }^{4}$

Art history and aesthetics, even as they grew out of the same institutionalized scholarly sphere, would henceforth always be marked out as a discretely differentiated field.

The separation of aesthetics and archeology got mapped onto the śâstra (theory) and prayoga (practice) divide, and led to a division of labour in which the question of meaning and interpretation was seen as the realm of specialized Sankrit-based scholarship dissociated from the empirical study of artifacts, with the latter thought to lie in the domain of archeology.

Reflecting on Indian intellectual history, Sheldon Pollock touches upon the imbrication of power in the Indian intellectual tradition around śästra-prayoga (Pollock 1984, 499-519). Seldom has modern art history in India responded to the issue of the caste hierarchy that has existed between the Brahmin authors of the śilpaśāstras and the low caste śilpins or artisans who practiced art (Misra 1975). Kramrisch $(1985,61)$, in fact, was one of the first art historians to examine caste in the context of art practice and point out contradictory views about labour and caste often held by the Dharmaśāstras:

4 Abanindranath Tagore, who spearheaded the Bengal School, wrote an article, "Shadangas or The Six Limbs of Painting" in 1915. It claimed to base its interpretation of Indian aesthetics on a verse culled from the Kāmasūtra of circa $500 \mathrm{CE}$. This elicited a vehement critique from an archeologist, Akshay Kumar Maitreya, and illustrates the conflict between aesthetics and archeology, as pointed out by Guha-Thakurta (1991). 
Manu says that the hand of a craftsman engaged in his work is always ritually pure. The Gautama Dharmaśāstra postulates that a Brahman may not accept food from an artisan. The law books thus distinguish the craftsman in his social position on one hand, and in his state of grace on the otherwhen he is engaged in his work, when he creates, and, thereby, gives effect to his being an embodiment of Viśvakarma.

Despite Kramrisch's attention to caste and its implication for the system of patronage and art practice, the model created by Coomaraswamy of the silp $\bar{\imath}$ or an artist/artisan aligned with transcendentalism remained dominant. Even Kramrisch later began to follow this line of thought $(1985,57)$ :

As artists and magicians, the Indian craftsmen transmuted matter into form, vision into concrete shape, and man beyond his earthy competence ... Charged with this power their work became concretely real, subtly effective, and transcendentally existent ....

\section{$6 \quad$ Reading Sādṛśya through Ethnography}

Since the time of the modern discovery of the śilpaśāstras and particularly with reference to texts on architecture, ethnography has emerged as a valid method of interpreting difficult terminology. As early as Ram Raz's attempt to make sense of obsolete terminology around 183os, recourse to extant practice was sought as a way of checking the extent to which śāstric terms had purchase with craftsmen. The question that I would like to raise here is the usefulness of ethnography in the interpretation of terms that deal with the 'resemblance' or 'truthfulness' of visual representation. Where are we placed today in terms of our understanding of this terminology, and to what extent is combining ethnography with the study of śilpa texts useful for shedding light on its slippery semantics?

Samuel Parker $\left(2003,5^{-34}\right)$ has been at the forefront of embracing the ethnographic approach in the study of texts mainly on architecture. Can this method be equally illuminating in the study of the silpaśāstras? Do critical terms that relate to visual representation-anukrti (imitation or mimesis), sādrśya (resemblance or verisimilitude), viddha (literally "pierced," or capturing resemblance), aviddha (that which lacks resemblance), etc.- -hold resonance for traditional idol makers? Here perhaps we need to distinguish between technical terms for parts of a building and terms that deal with aesthetics (beauty) and visual representation. Terms that deal with complex semiotics 
such as sādrśya, beauty, etc., are too culturally loaded for them to travel well across time. Perhaps in this regard it is instructive to turn to British art historian, Michael Baxandall (1972, 26), who has brought to our notice how some art terminologies common in fifteenth-century Italy, which had made perfect sense to their contemporary public, resist easy comprehension for today's audience.

Ethnography, as employed by some Indologists, assumes continuity of meaning across time such that by recourse to extant practice by modern sthapati (traditional architects) the meanings of traditional treatises can be unlocked. Terms such as sādrśya are ensconced in a whole web of meanings and practices of viewing that make them intelligible, and in the absence of the latter, they often give rise to skepticism around śilpaśāstras — as if what they say fails to coincide with what they really mean.

Besides, do terms like sādrśya or satya, no doubt used in classification of paintings in terms of degrees of correspondence to the visible world as far as the Citrasütra is concerned, have the same valence as technical terms that classify a building? Or, as demonstrated by the survey of the historiography of textual interpretations, terms dealing with visual representation are seen by cultural nationalists as too invested in civilizational identity and the marking of cultural difference to yield an 'objective' meaning. More recently, Isabella Nardi has ventured into this fraught zone and attempted to employ the ethnographic approach to analyze how a present-day traditional idol maker engages with visual representation and beauty. Nardi has interacted with local sculptors in Orissa and Rajasthan to explore the relevance of the silpaśāstras to their current practice (Nardi 2006, 58-63).

In her conversation with a local sculptor, Ram Prasad Sharma, Nardi was struck by Sharma's comparison of the sculpture of Lakshmi with a European Renaissance master, Giovanni Bellini's Young Woman with a Mirror (painted in 1515), only to demonstrate the greater beauty of the former (2006, 6o):

Applying his rules and ideals, the sculptor explains that the major defects of this Renaissance figure are that the woman has a huge belly and very big arms.

Likewise, Nardi (ibid.) attributes this sculptor's failed attempt at copying Michelangelo's sculptures to "different vocabulary and aesthetic ideals of the Indian sculptor and [the] Renaissance [sculptor]." Such an ethnographic exercise, while shedding light on the gap between text and practice, serves to underline cultural difference and tends more towards truisms about how each cultural practitioner responds to aesthetics through what is locally familiar than to clarify meanings embedded in texts. 


\section{"Mistranslation" of Sanskrit Terms: A Paradigm for Rethinking Visual Representation in Indian Art}

There is no simple, pure unproblematic naturalism in the Indian tradition waiting to be recuperated. The very fact that there is no one-to-one translation possible in Sanskrit, for example, opens up an area of interrogation and also a paradigm for interpretation. Perhaps we have neither the words nor the concepts to capture the domain of "naturalism."

Kapila Vatsyayan insightfully problematizes the question of naturalism in the context of premodern India thus (Dave-Mukherji 2001, xii):

For a fuller examination, it would be necessary to reopen the question of what constitutes as Nature in the Indian mind-scape, more precisely, the mahäbhütas and prakrti. This comprehension has to be clearly distinguished from the emergence of 'naturalism' as an art movement in Europe in the 18 th and 19 th centuries.

Of course, the absence of a single term does not signify that the concept does not exist. Rather, the absence itself can be seen as an important clue. Perhaps what we have is a much more complex experience which can be described by using a combination of sādrśya, satya and anukrti. In the same way, Sanskrit terms such as kșayavrddhi (literally, diminution and expansion) or vartana need not be directly taken as equivalents of "foreshortening" or "shading." The lack of a close fit between them and the gaps opening up as we attempt to map one set of Sanskrit terms on another set of English terms may itself signify a rich terrain to explore.

Once it is acknowledged that that no mode of visual representation in any given culture in the West or elsewhere has a direct, unmediated and privileged access to the visible, it makes futile any defensive and anxious search for an "Indian naturalism." In Art History, Norman Bryson (1983) has engaged with a post-structuralist critique of representation and argued against any unmediated access to the real, a view that helps us to complicate the issue of naturalism even in the context of premodern Indian art.

In more recent times and a context closer to South Asia, the question of 'the real' has assumed new significance in the writings of David Shulman, who has added a more specific dimension to this inquiry through his focus on South Indian models of mind. I would conclude by juxtaposing Coomaraswamy's anti-naturalism with Shulman's evocation of the 'more than real.' At one level, one may discern a certain correspondence between Coomaraswamy's rejection of naturalism as alien to the Indian sensibility, a construct created under the 
sway of cultural nationalism, and Shulman's recognition of a different model of mind for South Asia that allows for an interplay between the real and the imagined. At the same time, it is possible to recognize a distinction between their models. While Coomaraswamy's view of naturalism arose out of a desire to defend Indian art from colonial denigration, Shulman-despite his focus on South India-complicates any simple binaries of the real and the imaginary; this he does by refusing a separation between an observing subject and observed real, instead posing their mutual permeability. Notwithstanding the fact that Shulman arrives at this model through a close reading of literary texts, it has important implications for notions of visual representation.

Once we overcome the defensive rejection of 'the real' and resituate the real at the cusp of the existing and the imaginary, the sāstric terminology can be accessed in new ways. The term vāyugati is a case in point. I would like to express my gratitude to Alexis Sanderson for pointing out the 'literal' meaning of vāyugati when I was editing the Citrasütra as his D.Phil. student in Oxford in the late 1980s. This term appears in the description of hallmarks of a skilled artist, the citravid, in the last adhyāya of the Citrasūtra, and sets up a high standard of verisimilitude for artistic practice: an expert must have an ability to depict parts of the body (or difficult transitional points) normally covered by ornaments like the neck, wrists, feet and ears; a body wounded by an arrow; an old person; he must create differentiation between a sleeping and a dead body, and an illusion of an apparent undulation of a flat surface. It is in this context of technical mastery over representation that vāyugati appears as a further marker of a skilled painter (Dave-Mukherji 2001, 250251):

\section{tarañgāgnišikhādhūmaṃ vaijayantyāmbarādikam} vāyugatyā likhed yas tu vijñeyah sa tu citravit

He who is able to paint waves, flames, smoke, flags and garments etc. with the speed of the wind (vāyugatya $)$ is considered to be an expert.

Previous editors of the Citrasūtra, who include Stella Kramrisch, A.K. Coomaraswamy, C. Sivaramamurti and Priyabala Shah, have overlooked the performative dimension of vayyugati. They have considered its representational meaning and connected it with the objects to be depicted, such as flames, banners and clothes that are windswept (vāyugati). Vāyugati can also connect with the agent of representation, i.e. the citravid or the expert in painting, who must paint flames, banners and clothes with the speed of the wind. If the first sense locates the objects to be drawn, such as flames, banners and clothes, in the lived 
and observable world, the second meaning implies artistic labour and skill, and above all points to the temporality of execution as an index of mastery over representation. Either way, it helps to recast the image of a traditional painter, not as creating images out of a meditative trance through half open eyes and duplicating formula from the past, but as one who encounters the world with keen eyes, trained hands and a vibrant imagination.

\section{References}

\section{Primary Sources}

Viṣnudharmottarapurāna. Pandit Madhusudhan and Madhavaprasada Sarma, eds. Visnudharmottara Purana. Khanda III. Chapters 1-118. Bombay: Venkateshwar Press, 1912.

Viṣnudharmottarapurāna. Parul Dave-Mukherji, ed. Citrasūtra of the Vișnudharmottara Purāna. Khanda III. Chapters 35-43. New Delhi: Motilal Banarsidass, 2001.

Vișnudharmottarapurānana. Priyabala Shah, ed. Viṣnudharmottara-Purāṇa. Third Khạnda. Chapters 1-118. 2 vols. Gaekwad Oriental Series, nos. 130 and 137. Baroda: 1958 and 1961 .

\section{Secondary Sources}

Asher, Frederick, 2007. "The Shape of Indian Art History." In Asian Art History in the Twenty-First Century, edited by Vishakha Desai, 3-14. New Haven: Yale University Press.

Baxandall, Michael. 1972. Painting and Experience in Fifteenth Century Italy. Oxford: Clarendon Press.

Bryson, Norman. 1983. Vision and Painting: The Logic of the Gaze. New Haven: Yale University Press.

Coomaraswamy, A.K. 1908. The Aims of Indian Art. London: Essex House.

Coomaraswamy, A.K.. 1933. "Vishnudharmottara Chapter 41." Journal of American Oriental Society 52: 13-21.

Coomaraswamy, A.K.. 1933. "The Painter's Art in Ancient India, Ajanta." Journal of the Indian Society of Oriental Art I: 26-29.

Coomaraswamy, A.K.. 1934. The Transformation of Nature in Art. Cambridge, MA: Harvard University Press.

Dave-Mukherji, Parul. 2008. "The Citrasūtra and the Politics of Authenticity." In Tattvabodha, edited by Kalyan Kumar Chakravarty, 125-140. New Delhi: Munshiram Manoharlal Publishers.

Dehejia, Harsh. 1996. The Advaita of Art. New Delhi: Motilal Banarsidass.

Dhareshwar, Vivek. 2015. "Sites of Learning and Intellectual Parasitism: The Case for 
New Humanities." Journal for Contemporary Thought (A Special Number on Critical Humanities), 41 (Summer): 57-77.

Guha-Thakurta, Tapati. 1991. The Making of a 'New' Indian Art: Artists, Aesthetics, and Nationalism in Bengal, C. 1850-1920. Cambridge: Cambridge University Press.

Halbfass, Wilhelm. 1981. India and Europe: An Essay in Understanding. Albany: State University of New York.

Kramrisch, Stella. 1922. "The Expressiveness of Indian Art." Calcutta Review 3 (October): $1-46$.

Kramrisch, Stella. 1928 [1924]. The Visnudharmottaram: A Treatise on Indian Painting and Image-Making. Calcutta University Press. Originally published as "A Treatise on Indian Painting." The Calcutta Review 2 (February 1924): 331-386.

Kramrisch, Stella. 1983. "Traditions of the Indian Craftsmen." In Exploring India's Sacred Art, edited by Barbara Stoler Miller, 59-68. Philadelphia: University of Pennsylvania.

Lipsey, Roger. 1977. Coomaraswamy. Volume 3: His Life and Work. Princeton, NJ: Princeton University Press.

Masson-Oursel, Paul. 1925. "Une connexion entre l'esthétique et la philosophie de l' Inde: la notion de pramâna." Review des Arts Asiatique 2 (1): 6-9. Translated into English by Coomaraswamy as "A Connection between Indian Aesthetics and Philosophy in India." Rupam 27 \& 28 (1926): 91-94.

Matilal, B.K. 1986. Perception: an Essay on Classical Indian Theories of Knowledge. Oxford: Clarendon Press.

Maxwell, T. S, 1989, "Śilpa versus Śāstra." In Shastric Traditions in Indian Arts, vol. 1, edited by Anna Libera Dallapiccola, 5-15. Stuttgart: Steiner Verlag Wiesbaden GMBH.

Misra, R.N. 1975. Ancient Artists and Art Activity. Shimla: Indian Institute of Advanced Studies.

Nardi, Isabella, 2006. The Theory of Citrasutras in Indian Painting: A Critical Re-evaluation of their Uses and Interpretations. London, New York: Routledge.

Parker, Samuel K. 2003. "Text and Practice in South Asian Art: An Ethnographic Perspective": Artibus Asiae 63 (1): 5-34. www.jstor.org/stable/3249692.

Pollock, Sheldon. 1984. "The Theory of Practice and the Practice of Theory in Indian Intellectual History." Journal of the American Oriental Society 105: 499-519.

Raghavan, V. 1933. "Some Sanskrit Texts on Painting." Journal of Indian Historical Quarterly 9: 904-905.

Ruskin, John. 1905. "Aratra Pentilici." Chapter 6 in The Collected Works of John Ruskin, vol. 2o. London: George Allen; New York: Longmans, Green, and Co.

Shah, Priyabala. 1958/1961. See Viṣnudharmottara Purāṇa.

Shulman, David, 2012. More than Real: A History of the Imagination in South India. Cambridge, ma: Harvard University Press. 
Sivaramamurti, C. 1978. The Chitrasutra of the Visnudharmottara. New Delhi: Kanak Publications.

Sivaramamurti, C. 1934. "The Artist of Ancient India." Journal of Oriental Research 8: 168-199. 